EFFECTIVE MANAGEMENT OF RESEARCH AND DEVELOPMENT 
By the same author

INERT ATMOSPHERES

HIGH-EFFICIENCY AIR FILTRATION 


\section{EFFECTIVE MANAGEMENT OF RESEARCH AND DEVELOPMENT}

P. A. F. WHITE, O.B.E., B. Sc., C. Eng., F. I. Mech. E., F. I. Chem. E.

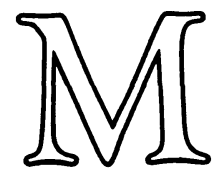


○ P. A. F. White 1975

Softcover reprint of the hardcover 1st edition 1975 978-0-333-17260-5 All rights reserved. No part of this publication may be reproduced or transmitted, in any form or by any means, without permission.

First published 1975 by THE MACMILLAN PRESS LTD London and Basingstoke Associated companies in New York Dublin Melbourne Johannesburg and Madras 


\section{Contents}

Preface ix

I INTRODUCTION 1

Unique characteristics of R \& D management 2

Changing nature of research management (the justification of $R$ \& D) 3

Meaning of research and development 5

(Place of R \& D in Cash Flow of a project) 8

Invention and innovation 9

Chief activities of an R \& D department (effect of organisational aims on balance of effort) 9

The management role $\quad 11$

Objectives of the book $\quad 14$

Pay-off of improved management $\quad 15$

Summary 15

2 GENERAL CONSIDERATIONS OF R \& D ACTIVITIES 17

Total national expenditure on R \& D $\quad 18$

Expenditure by different sectors 21

Expenditure in universities and research associations $\quad 24$

Cost per professional scientist 25

Research in industry 26

Effect of size of firm (special situation of small firms)

Internal v. external research 33

Data from USA 34

Profitability and research ratio $\quad 42$

The customer/contractor relationship $\quad 44$

Summary $\quad 46$ 
3 THE STRUCTURE OF R \& D ORGANISATIONS

From large government laboratories to small industrial laboratories

Purpose of laboratory

The structure of R \& D organisations

Horizontal structure

Vertical structure

The nature of organisations

The structure of organisations

Hierarchical structure in research establishments

Size of research establishment v. effectiveness: economies of scale

Relation between research and design

Relation between internal and external research

Summary

4 AVAILABLE SOURCES OF RESEARCH EFFORT

Universities and polytechnics

Government departments

Technical spin-off from advanced R \& D

Government laboratories

Research associations

Sponsored research institutes

Consultants

National Research Development Corporation (NRDC)

Research in industry

Social implications of science

Summary

5 THE CHOICE OF AN R \& D PORTFOLIO

Objective decided

Objective known generally

Objective unknown

Source of new research ideas

Selection of portfolio

Study of an actual portfolio in US industry

Quantitative analytical methods of project selec- 
PABLA 134

Critical path planning and branched networks $\quad 139$

Cost benefit analysis $\quad 146$

Choice of research project - appraisal graphs $\quad 150$

Benefits of using formal project review 151

Defining project to 'customer' requirements 152

Changing the portfolio-stopping projects $\quad 156$

Technology assessment $\quad 160$

$\begin{array}{ll}\text { Summary } & 161\end{array}$

6 CONTROL OF R \& D PROJECTS 163

General management role $\quad 163$

Budgeting and cost control 165

Critical path networks for control of research projects

Management by exception

Management by objectives

Cash flow diagrams as control techniques

Communications

Communications in the laboratory

Difference between management and direction

The end-point of project-orientated research

Patents and positive publication policy

Summary

7 EFFICIENCY AND PRODUCTIVITY IN R \& D 202

The place of efficiency in $R$ \& D

Economy of experimentation

202

Scale of experimentation

204

206

Tools of research

207

Measuring productivity in R \& D 208

Techniques for the efficient use of staff $\quad 212$

Use and control of labour $\quad 214$

Job evaluation $\quad 216$

Work study/activity sampling $\quad 217$

Engineering services $\quad 219$

Using the available system $\quad 221$

Summary $\quad 221$

8 STAFF SELECTION, DEVELOPMENT AND

MANAGEMENT

Recruitment and promotion 
viii

Staff development

Management of staff in R \& D environment 232

Organisation and freedom

Power and conflict within organisations

Summary

9 LABORATORY PLANNING AND ADMINISTRATION

General planning

Relationship with architect/engineer

Selection of site

Control of building activities

Commissioning and take-over

Laboratory management

Summary

10 TECHNICAL ASSISTANCE TO R \& D STAFF

Services - direct and indirect

Information and library services

259

Engineering services

Administrative controls

261

Safety

263

Consultants

265

Human sciences

266

Summary

268

11 LEADERSHIP IN RESEARCH

ORGANISATIONS

Analogy with orchestral playing

Place of individual research worker

Maintaining high standards

Leadership

Typical responsibilities of head of R \& D department

Attributes of research leader

Summary

References

Index 


\section{Preface}

The Research and Development scenario has undergone a substantial change over the last decade or so. From a setting in which total effort was expanding rapidly with a faith that more R \& D was inevitably rewarding, has come the much more critical atmosphere in which, firstly, efforts were made to increase the productivity of research and, secondly, much greater perception of the necessity of fitting research to social needs has arisen.

The move towards quantifying or at least logical planning of research has become more refined while the relationship of $R$ \& D to 'marketability' factors has also assumed greater importance. Methods of inspiring creativity in relation to innovation have received much attention as have the nature of the structure of scientific organisations and methods of managing creative scientists.

This book is concerned with the situation as it appears nowwith the rational tools available for assisting in management, with the many aspects of increasing efficiency and productivity in the laboratory and with the many factors which go to directing a successful R \& D effort tuned to the needs of its parent authority from customer/contractor relationship to methods of structuring R \& D organisations and management styles. Data related to expenditure on $R \& D$ in various fields is given for both the UK and the USA.

It may be that the refinement of the tools for such rationalisation of the management of R \& D has sometimes misguided managers into forgetting that it is still the quality of the output of the front-line researchers which decides whether advances are feasible and this book continually emphasises the need for creating the right environment for researchers as the prime task of the $\mathrm{R} \& \mathrm{D}$ management.

Literature on the subject of R \& D management was prolific about a decade ago, when the new quantifiable techniques 
were first gaining recognition but is harder to find in relation to the present outlook. This book is written largely from the author's experience as the Head of the Division of Chemical Technology at the UKAEA Aldermaston (now Ministry of Defence) for the last sixteen years together with experience of industrial and civil service research before that, as well as from much of the literature of recent years.

It is felt that it is now timely for a book to appear on the present changed scenario. It is hoped that it will be of help to those already engaged in the managing and directing of research and to those who aspire to such a goal. It should also be of value to students in universities and polytechnics, particularly in the technological disciplines, who wish eventually to work in some field of applying research to practical problems or any others who seek a text for training in the wider issues of managing the application of research. Managers of other departments than the research department might find this book useful to tell themselves of the nature of the problems of their technical colleagues.

There are many people who have played a part indirectly in the production of this book - particularly the many staff at AWRE Aldermaston with whom the methods of managing large and small scale $R$ \& D enterprises were jointly forged over the years.

More directly I should particularly like to thank Dr J. W. Weale, Superintendent of Nuclear Physics at AWRE Aldermaston for help in methods of applying management by objectives in the research field; $\mathrm{Mr} \mathrm{R}$. L. Latham, Senior Superintendent, Engineering, at AWRE Aldermaston for help in relation to his own development of Problem Analysis by Logical Approach; Dr P. M. S. Jones, Head of the Programmes Analysis Unit, Chilcott, Harwell, for information regarding cost/benefit analysis studies; $\mathrm{Mr} \mathrm{A}$. J. Richards of the Department of Trade and Industry for up-to-date information about the industrial research associations.

Acknowledgement is also due to each of the following for permission to reproduce figures: Chapman \& Hall Ltd (Figures 5.7-5.10), Her Majesty's Stationery Office (Figure 4.1), International Communications Ltd (Figure 7.1) and the United Kingdom Atomic Energy Authority (Figures 1.2 and $1.3)$. 